\title{
Analysis of the effects of isotretinoin on the premature epiphyseal closure in pediatric populations: a literature review
}

https://doi.org/10.1515/jom-2021-0108

Received April 13, 2021; accepted August 20, 2021;

published online October 11, 2021

\begin{abstract}
Context: Oral isotretinoin, a systemic retinoid and a vitamin A derivative, has been widely utilized to treat acne in both adult and pediatric populations. Additionally, systemic retinoids have also been utilized to treat neuroblastoma in pediatric patients. Common side effects associated with oral isotretinoin include dry eyes, dry mouth, elevated liver enzymes, depression, and arthralgia. Less common side effects of isotretinoin include hearing loss, pseudotumor cerebri, anaphylaxis, and skeletal abnormalities including growth arrest. The U.S. Food and Drug Administration (FDA) has received reports of premature epiphyseal closure in patients treated with isotretinoin retinoids, which are commonly prescribed by primary care providers as a treatment for acne. It is important to raise awareness of the potential side effects of isotretinoin to enable informed treatment decisions before beginning an isotretinoin regimen.
\end{abstract}

Objectives: This chapter aims to elucidate that isotretinoin, given at various doses and durations, has been associated with growth plate abnormalities, which can lead to premature epiphyseal closure.

Methods: Two databases were utilized for the literature review and were conducted at different time periods. Our literature review was conducted between December 2020 and June 2021, utilizing PubMed with the following search terms: "isotretinoin" and "isotretinoin and premature epiphyseal closure.” In April 2021, we searched the FDA's "Drug Data and Adverse Event Report System" utilizing the terms "isotretinoin" and "epiphysis premature fusion.” We included in our query reports of patients worldwide under

*Corresponding author: Sama Alazawi, DO, Touro University College of Osteopathic Medicine, 1310 Club Drive, Vallejo, CA 94592-1187,

USA, E-mail: alazawisama@gmail.com

Tami Hendriksz, DO, Department of Pediatrics, Touro University

College of Osteopathic Medicine, Vallejo, CA, USA
18 years of age with premature epiphyseal closure or growth plate damage secondary to isotretinoin. Studies published in English between 1980 and 2020 were also included, as well as background sources relating to an isotretinoin profile with side effects and dosing. We narrowed our search to exclude patients with a history of growth plate disorders due to trauma, malignancy, or other pathological processes, as well as patients with growth arrest due to endocrine factors. Growth plate abnormalities associated with retinoid derivatives other than isotretinoin were also excluded.

Results: A total of 28 items were selected for our literature review including: one FDA drug label, one FDA website of adverse reactions, 19 supplemental articles, six case reports, and one case series of premature epiphyseal closure secondary to isotretinoin. The FDA received 41 reports worldwide of premature epiphyseal closure related to isotretinoin in patients under 18 years of age. Additionally, premature epiphyseal closure and growth plate abnormalities occurred in nine patients with various durations and doses of isotretinoin ranging from the lowest dose of $0.5 \mathrm{mg} / \mathrm{kg} /$ day for a few months to $3.5 \mathrm{mg} / \mathrm{kg} /$ day for years. Conclusions: Isotretinoin-induced premature epiphyseal closure and growth plate deformities seem to be linked to higher doses of isotretinoin for the duration of months to years. There have been reported cases of premature epiphyseal closure in individuals receiving therapeutic doses of isotretinoin for acne treatment, which are much lower compared to the high doses utilized for neuroblastoma. Based on this study, isotretinoin appears to impact the growth plates of proximal tibia and distal femur. A cause-and-effect relationship between isotretinoin and premature epiphyseal closure cannot be concluded.

Keywords: drug effects; growth failure; isotretinoin; pediatrics; premature epiphyseal closure.

Isotretinoin, better known by its brand-name Accutane, is a vitamin A derivative primarily utilized for the treatment of acne in both adult and pediatric populations [1]. It works by inhibiting sebaceous gland functions. For children over 12 years of age, the recommended dose for the treatment of 
severe acne and moderate acne refractory to other treatment is $0.5 \mathrm{mg} / \mathrm{kg} /$ day for 4 weeks, and it then may be titrated as tolerated up to $1 \mathrm{mg} / \mathrm{kg} /$ day for a total cumulative dose of $120 \mathrm{mg} / \mathrm{kg}$ [2]. Oral isotretinoin is administered at higher doses of $160 \mathrm{mg} /$ day for 14 consecutive days for children with neuroblastoma, a tumor of the adrenal glands that most commonly affects children 5 years of age and younger. Multiple cycles of 6-8 doses may be needed depending on the evaluation of the tumor [3]. Additionally, isotretinoin has been utilized at doses of $0.5-4 \mathrm{mg} / \mathrm{kg} /$ day for treating epidermolytic hyperkeratosis. Neuroblastoma and epidermolytic hyperkeratosis have sporadic prevalence, whereas acne vulgaris is common among the pediatric population. Retinoids may also be utilized as a prophylaxis for squamous cell carcinoma and for the treatment of T-cell lymphoma $[4,5]$.

Few cases of premature epiphyseal closure in patients with acne following the recommended doses of isotretinoin have been reported to the U.S. Food and Drug Administration (FDA) [6]. Clinical screenings are often performed to assess the side effects of isotretinoin on the liver, lipid profile, and other systemic symptoms, especially the risk of depression and suicide. However, currently, there is no clinical or laboratory screening to assess the risk of growth arrest in pediatric patients on therapeutic doses of isotretinoin for the treatment of acne. During the process retinoid-induced epiphyseal closure, lab values of calcium, phosphorus, and alkaline phosphate that indicate bone health are typically normal [7]. X-ray and MRI of long bones may be useful to the findings of growth plate disruption. In a few case reports, patients with premature epiphyseal closure complained of knee pain $[8,9]$. However, arthralgia is a common side effect of isotretinoin consumption, and it can mask the knee pain caused by growth plate fusion, potentially leading to a misdiagnosis. We will elaborate on reports of skeletal growth disruption following isotretinoin therapy exposure.

In addition to cases of premature epiphyseal closure, there are other adverse effects of isotretinoin use, including mucocutaneous effects of cheilitis (chapped lips) and xerosis (dry skin), which are both among the most common side effects reported. Other mucocutaneous side effects include epistaxis (nosebleed), desquamation (skin peeling), pruritis (itching), and photosensitivity. Ocular manifestations of isotretinoin include dryness, irritation, and conjunctivitis. Musculoskeletal effects of arthralgia, myalgia, and back pain are also common. There is also a possible link between isotretinoin and depression and suicide. Other less common side effects reported include bone mineral density loss, hearing loss, pseudotumor cerebri, pancreatitis, anaphylaxis, and hematuria [10]. Additionally, isotretinoin is teratogenic and can cause severe birth defects and spontaneous abortion [11]. Females of reproductive age who are taking isotretinoin are required to comply with the iPLEDGE Program, a pregnancy prevention program for female patients on isotretinoin [12].

Laboratory testing and clinical measurements are recommended to monitor the symptoms and side effects associated with the oral intake of isotretinoin including possible elevated liver enzymes, hyperlipidemia, dry eyes, and epistaxis. The patients' liver transaminases and lipid panels should also be monitored throughout the treatment course [13]. Patients are also routinely screened for depression and suicidal ideation [2]. However, growth screening of adolescents is not recommended as part of the clinical investigation for patients on therapeutic doses of isotretinoin for acne treatment [2].

Physiologic growth plate fusion varies in age among males and females. Growth plates were examined with MRI of 968 volunteers between the ages of 14 and 21.5 (481 females and 477 males) [14]. In this study, it was found that 50 and $90 \%$ of females had fused their growth plates at ages 14-17 and 15-18 years, respectively [14]. On the other hand, 50 and $90 \%$ of males had fused their growth plates at ages 15-18 and 17-20 years, respectively [14]. It is important to note that growth plate fusion due to normal physiology occurs at highly varying ages in both genders. Thus, the developing growth plates in adolescents may be susceptible to deformities related to isotretinoin at variable ages. $\mathrm{Pu}$ berty and adolescence also coincide with the development of acne. For this reason, many adolescents might be prescribed isotretinoin while their growth plates are still undergoing development and thus may have an increased risk of premature epiphyseal closure related to isotretinoin.

To understand the impact of isotretinoin on skeletal growth, we first need to explain the physiology of skeletal growth. Growth in height is determined by the vertical elongation of long bones, a process that is moderated by growth plates, which are also known as epiphyseal plates. The growth plate is the cartilaginous portion of the long bones, whose structure is comprised of chondrocytes suspended in a collagen matrix. A variety of humoral factors, including growth hormone, parathyroid hormone, estrogen, cytokines, and various signaling pathways, coordinate the process of endochondral ossification [15]. One study suggested that the retinoic acid may impact growth plate closure through the degradation of the cartilage matrix component [16]. In vitro, retinoic acid was added to calf cartilage cultures and demonstrated reduction in cartilage matrix synthesis and enhancement of the catabolism of cartilage proteoglycans [16]. On the other hand, the dosing of systemic retinoids may be important in determining the fate of the epiphyseal plate. In one study of 
guinea pigs treated with various doses of vitamin $\mathrm{A}$, the frequency of growth plate disruption increased at higher doses of vitamin A [17].

In this study, we investigate how isotretinoin at various doses and durations affects growth plates in pediatric populations through a literature review of case reports and FDA reports. We also aim to understand which parts of the growth plates are affected.

\section{Methods}

The literature review was conducted on 15 separate occasions between December 2020 and July 2021 utilizing PubMed with the following search terms: "premature epiphyseal closure." In April 2021, the terms "isotretinoin" and "epiphysis premature fusion" were queried on two separate occasions in the FDA's Drug Data and the FDA Adverse Event Reporting System database, respectively. The terms were identified on MeSH (Medical Subject Headings) as “isotretinoin/administration \& dosage," “databases, pharmaceutical," "growth plate/drug effects," "isotretinoin/ therapeutic use," "failure to thrive/chemically induced," "growth plate/pathology," and "arthralgia/pathology."

In the FDA's drug database, the search term "isotretinoin" was utilized. In the FDA Adverse Event Reporting System database, the keyword "epiphysis premature fusion" was searched by reaction term. Our search was further narrowed utilizing filters for the term "isotretinoin."

Utilizing the PubMed and FDA Adverse Event Reporting System databases, we identified additional studies through a citation review of key articles. Excluding duplicates, we identified 308 studies in our initial search. We then screened the studies for eligibility utilizing the title and keywords "premature epiphyseal closure \& isotretinoin/retinoid/vitamin A" or "isotretinoin"; this narrowed our results to 32 studies. Of these 32 studies, 28 were selected and four were excluded. We included in our selection reports of patients worldwide under 18 years of age with premature epiphyseal closure or growth plate damage secondary to isotretinoin, and we limited our selection to articles published in the English language between 1980 and 2020. We also included background sources relating to isotretinoin's profile with side effects and dosing. We further narrowed our search to exclude patients with a history of growth plate disorders due to trauma, malignancy, or other pathological processes, as well as patients with growth arrest due to endocrine factors. Growth plate abnormalities associated with retinoid derivatives other than isotretinoin were also excluded. Figure 1 shows the PRISMA diagram.
Alazawi designed the study and conducted the initial search, review, and analysis of the data. Hendriksz conducted a further literature review, and both authors reviewed the results together. Studies that followed the inclusion criteria were utilized. Alazawi and Hendriksz agreed to include patients under 18 years of age with premature epiphyseal closure or growth plate damage secondary to isotretinoin. Additionally, both authors agreed on the exclusion criteria.

\section{Results}

In total, 32 items were found, of which 28 were included and four were excluded based on the foregoing criteria. Two case reports of patients on retinoid therapy with a history of growth hormone deficiency and premature epiphyseal closure were excluded. Case reports of growth plate abnormalities associated with other retinoid derivatives, such as fenretinide and etretinate, were also excluded because of their different pharmacokinetic profiles compared to isotretinoin $[18,19]$. We also excluded studies of premature epiphyseal closure due to trauma and fractures.

Eventually, a total of 28 items were selected, including: one FDA Drug Label of Accutane (brand-name for isotretinoin), one FDA website of adverse reactions, 19 supplemental articles, six case reports, and one case series of premature epiphyseal closure secondary to isotretinoin. Premature epiphyseal closure and growth plate abnormalities were associated with various durations and doses of isotretinoin ranging from the lowest dose of $0.5 \mathrm{mg} / \mathrm{kg} /$ day for a few months to $3.5 \mathrm{mg} / \mathrm{kg} /$ day for years.

Between 1985 and 2021, the FDA received 41 reports worldwide of premature epiphyseal closure related to isotretinoin in patients under 18 years of age. Of those 41 reports, 22 reports were for the treatment of acne, one report was for the treatment of epidermolysis bullosa, and 18 reports had unspecified reasons for utilizing isotretinoin [20]. The data were extracted from the FDA Adverse Event Reporting System database and reorganized to highlight the key elements of the study [20]. Table 1 shows the results of the FDA reports. We omitted any duplicate reports and those with adult patients (over 18 years of age).

In the review of six case reports and one case series selected, nine patients were found to have growth plate abnormalities related to isotretinoin therapy. Table 2 highlights the pertinent findings of the case reports and case series. In the Duvalyan et al. case series study, three of the 216 pediatric neuroblastoma patients developed irreversible premature epiphyseal closure after Isotretinoin 


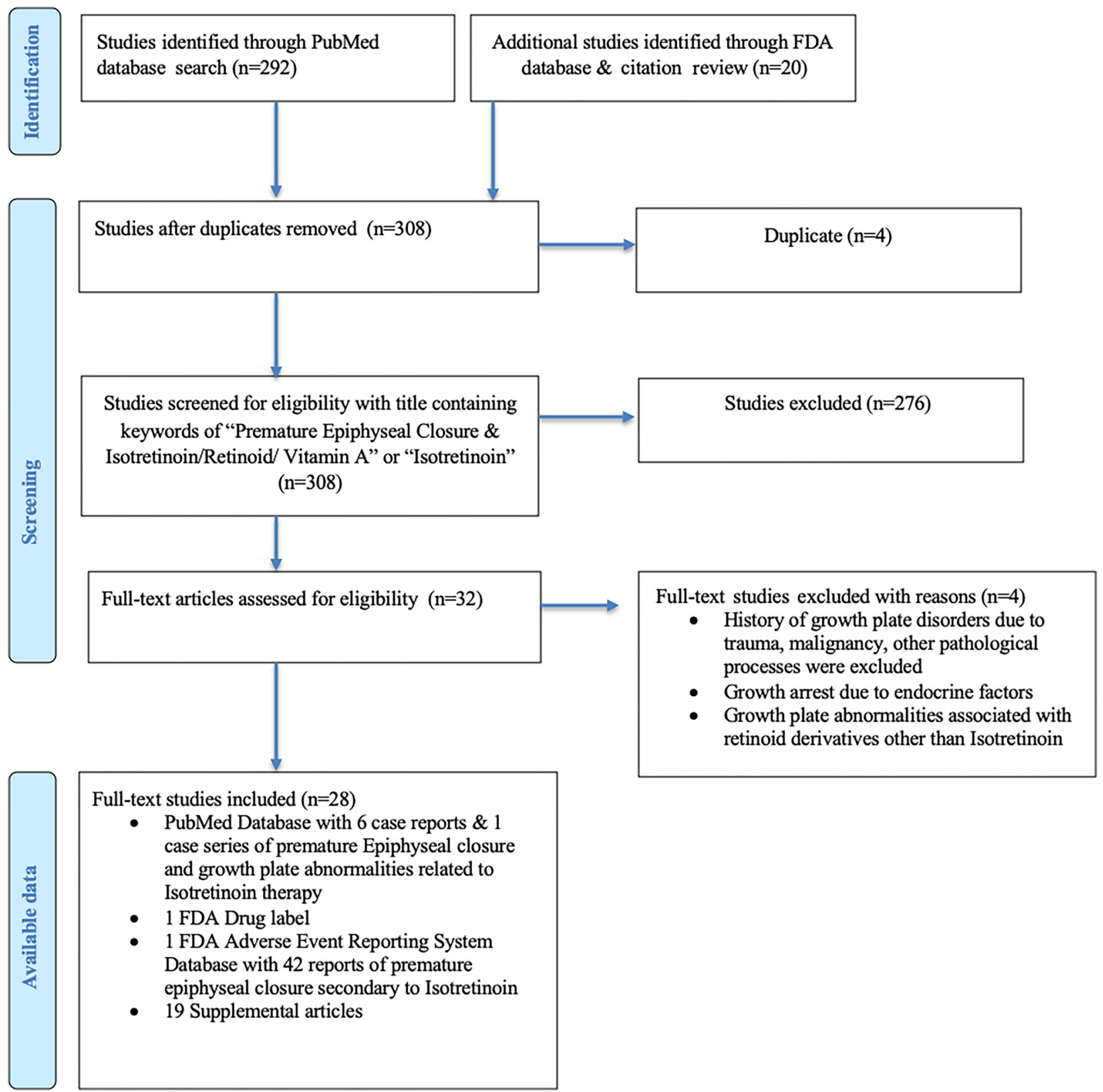

Figure 1: PRISMA diagram.

exposure with an incidence rate of $1.4 \%$ [21]. Imaging of these three patients at ages 9,10 , and 11 revealed premature epiphyseal closure of the bilateral knees following isotretinoin doses of $160 \mathrm{mg} / \mathrm{m}^{2}$ at variable cycles [21].

In the case reported by Matsuoka et al., a 10-year-old female suffered irreversible arrest of the femoral and tibial plates after taking isotretinoin at the average dose of $40 \mathrm{mg} /$ day for 9.8 years to treat neuroblastoma [22]. Park et al. reported a case of a 10 -year-old male with premature epiphyseal closure of the knees likely related to isotretinoin therapy for neuroblastoma [23]. From the Milstone et al. paper, partial epiphyseal fusion of the right tibia was associated with isotretinoin therapy at an average dose of $3.5 \mathrm{mg} / \mathrm{kg} /$ day for a couple of years in a 10-year-old boy with history of epidermolytic hyperkeratosis [7]. Marini et al. reported reversible growth plate abnormalities of the knees in a case of a 9-year-old boy with fibrodysplasia ossificans progressive, who was treated with isotretinoin at a dose of $5 \mathrm{mg} / \mathrm{kg} /$ day for 5 months [24]. In two other case reports of patients being treated for acne, unilateral knee 
Table 1: FDA reports of epiphysis premature fusion and isotretinoin.

\begin{tabular}{|c|c|c|c|c|c|}
\hline $\begin{array}{l}\text { Patient age, } \\
\text { years }\end{array}$ & Sex & Reason for use & Reactions & Concomitant product names & $\begin{array}{l}\text { Initial FDA } \\
\text { received date }\end{array}$ \\
\hline 15 & Female & $\begin{array}{l}\text { Product utilized for } \\
\text { unknown indication }\end{array}$ & Epiphyses premature fusion & - & 07-Jan-2021 \\
\hline 14 & Male & Acne & Epiphyses premature fusion & - & 03-Mar-2020 \\
\hline 15 & Male & Acne & Epiphyses premature fusion & $\begin{array}{l}\text { Prednisone; ibuprofen; } \\
\text { vitamins }\end{array}$ & 06-Mar-2019 \\
\hline 13 & Male & $\begin{array}{l}\text { Acne; blood growth } \\
\text { hormone }\end{array}$ & Epiphyses premature fusion & Norditropin & 19-Jun-2018 \\
\hline 15 & Male & $\begin{array}{l}\text { Product utilized for } \\
\text { unknown indication }\end{array}$ & Epiphyses premature fusion & - & 07-Jul-2017 \\
\hline 14 & Female & $\begin{array}{l}\text { Epidermolysis bullosa; } \\
\text { ichthyosis }\end{array}$ & Epiphyses premature fusion & - & 20-Sep-2016 \\
\hline 15 & Male & $\begin{array}{l}\text { Acne; staphylococcus test } \\
\text { positive }\end{array}$ & Epiphyses premature fusion & $\begin{array}{l}\text { Klaron; Triaz; Dynacin; Septra } \\
\text { Ds; Cleocin T; Differin }\end{array}$ & 07-Mar-2005 \\
\hline 14 & Male & Acne & Epiphyses premature fusion & - & $15-$ Oct- 2014 \\
\hline 14 & Male & Acne & $\begin{array}{l}\text { Epiphyses premature fusion; body } \\
\text { height decreased; growth retardation }\end{array}$ & - & 06-Jun-2013 \\
\hline 14 & Male & Acne; asthma & $\begin{array}{l}\text { Epiphyses premature fusion; growth } \\
\text { retardation }\end{array}$ & Zyrtec & 01-Mar-2013 \\
\hline 16 & Male & - & Epiphyses premature fusion & - & $25-F e b-2011$ \\
\hline 13 & Male & Acne & $\begin{array}{l}\text { Epiphyses premature fusion; bone } \\
\text { disorder }\end{array}$ & - & 28-Oct-2009 \\
\hline 13 & Female & Acne & Epiphyses premature fusion & - & 28-May-2008 \\
\hline 13 & Male & $\begin{array}{l}\text { Product utilized for } \\
\text { unknown indication }\end{array}$ & $\begin{array}{l}\text { Epiphyses premature fusion; body } \\
\text { height below normal; growth } \\
\text { retardation }\end{array}$ & - & 07-Jun-2004 \\
\hline 16 & Male & $\begin{array}{l}\text { Product utilized for } \\
\text { unknown indication }\end{array}$ & Epiphyses premature fusion & - & 29-Apr-2005 \\
\hline 12 & Male & Acne cystic & Epiphyses premature fusion & - & 07-Jun-2004 \\
\hline 16 & Male & $\begin{array}{l}\text { Product utilized for } \\
\text { unknown indication }\end{array}$ & Epiphyses premature fusion & - & 22-Jul-2003 \\
\hline 16 & Male & Unevaluable event & Epiphyses premature fusion & Advil; vitamin E & 24-Jan-2002 \\
\hline 13 & Male & - & Epiphyses premature fusion & - & 06-Jun-2002 \\
\hline 13 & Female & - & $\begin{array}{l}\text { Epiphyses premature fusion; growth } \\
\text { retardation }\end{array}$ & - & 06-Jun-2002 \\
\hline 15 & Male & Acne cystic & Epiphyses premature fusion & Prednisone; ibuprofen & 11-Jun-2001 \\
\hline 16 & Male & Acne & Epiphyses premature fusion & - & 08-May-2002 \\
\hline 14 & Male & Acne & Epiphyses premature fusion & - & 15-Jun-2001 \\
\hline 14 & Male & Acne cystic & Epiphyses premature fusion & Zyrtec & 13-Jul-2001 \\
\hline 15 & Male & - & Epiphyses premature fusion & - & 11-Jun-2001 \\
\hline 18 & Male & Acne & Epiphyses premature fusion & - & 11-Jun-2001 \\
\hline 17 & Male & Acne & $\begin{array}{l}\text { Epiphyses premature fusion; growth } \\
\text { retardation }\end{array}$ & - & 11-Jun-2001 \\
\hline 12 & Female & - & Epiphyses premature fusion & - & 09-Jun-2000 \\
\hline 14 & Male & Acne cystic & Exostosis; epiphyses premature fusion & - & 09-Jun-1998 \\
\hline 15 & Male & Acne & Epiphyses premature fusion & - & 20-Mar-2000 \\
\hline 14 & Male & Acne cystic & $\begin{array}{l}\text { Epiphyses premature fusion; knee } \\
\text { deformity }\end{array}$ & - & 12-Jan-2000 \\
\hline 15 & Male & Acne cystic & Epiphyses premature fusion & - & 07-Jun-1999 \\
\hline 14 & Male & - & Epiphyses premature fusion & - & 09-Jun-1998 \\
\hline 14 & Male & Acne & Epiphyses premature fusion & - & 13-Jun-1996 \\
\hline 12 & Male & Acne & Epiphyses premature fusion & - & 05-Feb-1998 \\
\hline 4 & Female & - & $\begin{array}{l}\text { Epiphyses premature fusion; bone } \\
\text { disorder }\end{array}$ & - & 14-Aug-1997 \\
\hline 14 & Male & - & $\begin{array}{l}\text { Epiphyses premature fusion; growth } \\
\text { retardation }\end{array}$ & - & 11-Jun-1997 \\
\hline
\end{tabular}


Table 1: (continued)

\begin{tabular}{llllll}
\hline $\begin{array}{l}\text { Patient age, Sex } \\
\text { years }\end{array}$ & Reason for use & Reactions & Concomitant product names & $\begin{array}{l}\text { Initial FDA } \\
\text { received date }\end{array}$ \\
\hline 15 & Male & - & Epiphyses premature fusion & - & $06-J u l-1990$ \\
15 & Male & - & Epiphyses premature fusion & - & $07-$ Aug-1986 \\
15 & Male & - & Epiphyses premature fusion; growth & - & $07-$ Aug-1986 \\
& & & retardation & $10-M a y-1985$ \\
\hline
\end{tabular}

Table 2: Summary of pertinent findings of the case reports and the case series.

\begin{tabular}{|c|c|c|c|c|c|}
\hline Study & $\begin{array}{l}\text { Patient age at which growth } \\
\text { plate abnormality was discov- } \\
\text { ered, in years/sex }\end{array}$ & $\begin{array}{l}\text { Reasons for isotreti- } \\
\text { noin use }\end{array}$ & $\begin{array}{l}\text { Isotretinoin } \\
\text { dose }\end{array}$ & $\begin{array}{l}\text { Duration of isotret- } \\
\text { inoin therapy }\end{array}$ & $\begin{array}{l}\text { Location of growth plate } \\
\text { abnormalities }\end{array}$ \\
\hline $\begin{array}{l}\text { Duvalayan } \\
\text { et al., case } \\
\text { series }\end{array}$ & 9-year-old female & Neuroblastoma & $160 \mathrm{mg} / \mathrm{m}^{2}$ & $\begin{array}{l}\text { Variable cycles for } \\
\text { total of } 8 \text { months }\end{array}$ & $\begin{array}{l}\text { Bilateral knees (left prox- } \\
\text { imal tibia and right distal } \\
\text { femur) }\end{array}$ \\
\hline $\begin{array}{l}\text { Duvalayan } \\
\text { et al., case } \\
\text { series }\end{array}$ & 11-year-old male & Neuroblastoma & $160 \mathrm{mg} / \mathrm{m}^{2}$ & Variable cycles & $\begin{array}{l}\text { Bilateral knees (bilateral } \\
\text { distal femur) }\end{array}$ \\
\hline $\begin{array}{l}\text { Duvalayan } \\
\text { et al., case } \\
\text { series }\end{array}$ & 10-year-old male & Neuroblastoma & $160 \mathrm{mg} / \mathrm{m}^{2}$ & Variable cycles & $\begin{array}{l}\text { Bilateral knees (bilateral } \\
\text { distal femur and proximal } \\
\text { tibia) }\end{array}$ \\
\hline $\begin{array}{l}\text { Matsouka et al., } \\
\text { case report }\end{array}$ & 10-year-old female & Neuroblastoma & $\begin{array}{l}\text { Average of } \\
40 \mathrm{mg} / \text { day }\end{array}$ & 9.8 years & $\begin{array}{l}\text { Bilateral knees (bilateral } \\
\text { distal femur and proximal } \\
\text { tibia) }\end{array}$ \\
\hline $\begin{array}{l}\text { Park et al., case } \\
\text { report }\end{array}$ & 10-year-old male & Neuroblastoma & $60 \mathrm{mg} /$ day & 1 year & $\begin{array}{l}\text { Bilateral knees (bilateral } \\
\text { distal femur and proximal } \\
\text { tibia) }\end{array}$ \\
\hline $\begin{array}{l}\text { Milestone et al., } \\
\text { case report }\end{array}$ & 10-year-old male & $\begin{array}{l}\text { Epidermolytic } \\
\text { hyperkeratosis }\end{array}$ & $\begin{array}{l}\text { Average of } \\
3.5 \mathrm{mg} / \mathrm{kg} / \text { day }\end{array}$ & $2-4$ years & Right knee (proximal tibia) \\
\hline $\begin{array}{l}\text { Marini et al., } \\
\text { case report }\end{array}$ & 13-year-old male & $\begin{array}{l}\text { Fibrodysplasia ossifi- } \\
\text { cans progressiva }\end{array}$ & $5 \mathrm{mg} / \mathrm{kg} /$ day & 5 months & $\begin{array}{l}\text { Bilateral knees (bilateral } \\
\text { distal femur and proximal } \\
\text { tibia) }\end{array}$ \\
\hline $\begin{array}{l}\text { Luthi et al., case } \\
\text { report }\end{array}$ & 16-year-old male & Acne & $0.5 \mathrm{mg} / \mathrm{kg} /$ day & 6 months & Left knee (distal femur) \\
\hline $\begin{array}{l}\text { Steele et al., } \\
\text { case report }\end{array}$ & 14-year-old male & Acne & $0.75 \mathrm{mg} / \mathrm{kg} /$ day & 6 months & Right knee (distal femur) \\
\hline
\end{tabular}

epiphyseal deformities were associated with isotretinoin therapy at doses of 0.5 and $0.75 \mathrm{mg} / \mathrm{kg} /$ day for 6 months in 16-year-old and a 14-year old, respectively [8, 9].

Nineteen supplemental articles were selected: four articles with uses of isotretinoin, two articles with dosing guidelines for isotretinoin, four articles relating to the side effects of isotretinoin, one article about laboratory monitoring during isotretinoin therapy, three studies regarding the physiology of growth plate in adolescents, two articles about how isotretinoin impacts animals growth plates in vivo, two articles about the differences between isotretinoin and other retinoid derivatives such as fenretinide and etretinate, one article relating to acne and puberty, and one article looking at the incidence of isotretinoin prescriptions among adolescents.

\section{Discussion}

Growth plate arrest has been reported in doses between 0.5 and $3.6 \mathrm{mg} / \mathrm{kg} /$ day for a variable course of 6 months to several years [7-9, 21-24].

Most cases of growth failure are reported secondary to high-dose isotretinoin use for prolonged periods and are usually seen in the treatment of neuroblastoma. In one study, three out of 216 pediatric neuroblastoma patients 
developed premature epiphyseal closure after isotretinoin exposure with an incidence rate of $1.4 \%$ [21]. The dose utilized was $160 \mathrm{mg} /$ day for 2 weeks on the medication and 2 weeks off the medication for $6-8$ cycles. In another case report, a 10-year-old female developed epiphyseal fusion secondary to isotretinoin therapy. She had a history of metastatic neuroblastoma, sparing the growth plates, and was diagnosed at 3 months old. She was initially treated with chemotherapy for a few months followed by only a systemic retinoid at a dose of $40 \mathrm{mg} /$ day, with a total treatment period of 9.8 years, beginning at 1 year of age [22]. She was evaluated by orthopedic surgeons for knee pain and deformity caused by tibial and femoral growth plate fusion, with the diagnosis supported by X-ray images and pathology findings [22]. A histopathologic analysis of the patient's femoral growth plate showed degradation of the cartilage matrix without evidence of apoptosis in the growth plates. The irreversible degradation of the cartilage matrix was most likely secondary to isotretinoin [22]. Park et al. reported a case of a 10-year-old male with premature epiphyseal closure of the knees likely related to Isotretinoin therapy for neuroblastoma [23]. The patient was diagnosed with metastatic neuroblastoma to the left proximal humerus at the age of 6 years, for which he underwent chemotherapy and radiation. Following completion of the treatment, the boy then began isotretinoin therapy at a dose of $60 \mathrm{mg} /$ day for 1 year [23]. A CT scan of the child's knees showed sclerotic changes supporting the diagnosis of premature epiphyseal closure. Furthermore, an MRI showed focal closure of the left humeral growth plate, which is the area where the metastatic neuroblastoma was located and on which radiation therapy was focused [23]. Park et al. reported that the physeal closure of the left humerus was likely secondary to focused radiation therapy of that area [23]. However, the knees did not undergo any radiation therapy, and their skeletal pathology likely related to isotretinoin use [23].

In all reports of patients with a history of neuroblastoma, they underwent a series of chemotherapy and radiation therapy that may also contribute to skeletal deformities [21-23]. Both therapies can affect growth, and radiation may induce premature epiphyseal closure [23]. These therapies could potentiate the damage of isotretinoin on growth plates. Additionally, some patients had a history of metastatic neuroblastoma to bones with sparing of the growth plate, which could be a contributing factor to skeletal toxicity. Metastasis to other organs could possibly affect the growth plate development indirectly.

Retinoid derivatives can be administered for the treatment of the keratinization dermatologic disorders, including epidermolytic hyperkeratosis. In one case, a child with epidermolytic hyperkeratosis utilized 13-cis retinoic acid for 4.5 years and was diagnosed with partial tibial epiphyseal closure at 10 years old [7]. The patient started the treatment at 6 years of age at a dose ranging from 0.5 to $4.5 \mathrm{mg} / \mathrm{kg} /$ day for the first 2 years of treatment [7]. The dose was then adjusted to an average of $3.5 \mathrm{mg} / \mathrm{kg} / \mathrm{day}$ in the final 2 years of treatment [7]. The duration of the treatment was for a 6 month course on the drug separated by 4 week periods off the drug [7]. The patient had recurring right knee pain, which prompted him to receive an X-ray of the knees at 42 months posttreatment. The imaging showed diffuse demineralization with partial fusion of the proximal epiphyseal plate in the right tibia [7].

Another example of skeletal toxicity associated with systemic retinoids was a case of a 9-year-old male who was treated with isotretinoin for fibrodysplasia ossificans progressiva, who later developed changes to his epiphyseal plates [24]. The patient was given isotretinoin for 5 months at a dose of $5 \mathrm{mg} / \mathrm{kg} /$ day [24]. The child later reported knee pain and received a skeletal survey of his lower extremities that displayed growth line arrest and thick metaphyseal bands that were nonexistent on the pretreatment imaging [24]. His height was also monitored, and he lacked linear growth during the 5 months of treatment. As a result, his isotretinoin therapy was stopped. At his 3 month follow-up after stopping the retinoid, his X-ray showed decreased density of the metaphyseal bands and resumption of height growth [24]. This article emphasizes the importance of frequent height measurements in follow-up evaluations for patients receiving high-dose or long-term retinoids. A lack of height growth should be followed up by an X-ray of long bones. There are a variety of growth centers affected by isotretinoin, and some of the growth plate damage may be reversible, whereas other damage may be irreversible [25]. The point at which irreversible changes on the growth plate occurs secondary to isotretinoin cannot be delineated in this study, and further research into this topic is needed.

Between 1985 and 2021, the FDA received 41 reports worldwide of premature epiphyseal closure related to isotretinoin in patients under 18 years without any literature reference. [20] However, the cases reported to the FDA lacked pertinent patient information, including relevant medical history and how the diagnosis of premature epiphyseal closure was made. Thus, the level of evidence is low as to whether isotretinoin was associated with these reports.

Of the 41 FDA reports, 22 reports of premature epiphyseal fusion were associated with isotretinoin utilized for the treatment of acne [20]. In one study, it was found that acne affects $78 \%$ of females between 8 and 12 years old [26]. In another study, the mean onset of acne in males was age 
14.3 years [27]. Because acne affects adolescents frequently and isotretinoin has been the most effective therapy for acne, there has been an increased prescription of systemic retinoids during the growth stage of teenagers. One study that examined the Norwegian Prescription Database estimated that 32,085 out of 144,220 individuals ( 22\%) in the age group of 14-24 years old had received a prescription of isotretinoin from 2005 to 2015 to treat acne [28].

Additionally, cases of premature epiphyseal closure have been reported by Luthi et al. [8] and Steel et al. [9] in acne patients treated with low doses of isotretinoin. One such report describes a 16-year-old male in Switzerland who plays soccer and who was on $0.5 \mathrm{mg} / \mathrm{kg} / \mathrm{day}$ of isotretinoin therapy for acne for at least 6 months [8]. He complained of knee pain that prompted him to receive an MRI and X-rays of both knees [8]. The X-ray findings were normal, but the MRI showed epiphysiodesis and destruction of the growth plate, with irregular epiphyseal cartilage and associated edema, resulting in the diagnosis of retinoid-induced epiphysiodesis [8].

Another patient being treated for acne had growth plate derangement following a 6 month course of vitamin A treatment [9]. This 14-year-old male in Australia had a history of nonresponsive cystic acne and was treated with isotretinoin at a dose of $0.75 \mathrm{mg} / \mathrm{kg} /$ day for 6 months [9]. At 12 months posttreatment, the patient was evaluated with an $\mathrm{X}$-ray imaging of the long leg bones after spraining his knee during a rugby match [9]. The imaging revealed closure of the right lateral femoral physis causing right knee valgus. The other growth plates appeared normal [9]. The toxic effects of low-dose isotretinoin on the skeletal system can be attributed to a patient's genetic variability in metabolizing the drug and changing its pharmacodynamics [9]. In both cases reported by Luthi et al. and Steel et al., the patients received imaging of their joints to rule out a sports-related injury $[8,9]$.

Premature epiphyseal closure was an incidental finding in both of those patients who received imaging due to sports injuries. Thus, the incidence of growth plate fusion due to isotretinoin could be underestimated in patients who do not participate in sports and are less likely to receive an imaging workup. On the other hand, isotretinoin is highly efficacious for treating acne and preventing the subsequent risk of scarring. The potential risk of irreversible growth arrest needs to be weighed against the benefits provided by its use.

For osteopathic considerations, the first tenant of osteopathy states that the body is a unit. Osteopathic physicians should consider how isotretinoin targets not only the skin for therapeutic effects but also multiple organ systems including the skeletal system.
Our literature review was limited to the databases available to us at the time of our review. As a result, other applicable studies outside of those available databases may exist but were not included in our study. Additionally, few articles dated back to the 1980s and 1990s with limited imaging technology and resolution that could potentially not fully capture the radiographic findings associated with growth plate development and abnormalities. Another limitation would be small sample size of nine patients. FDA reports are limited on the doses of isotretinoin associated with premature fusion. A prospective study with a large population of adolescents to examine the development of growth plates while taking isotretinoin therapy would add strength to the current understanding of its effects.

\section{Conclusions}

Isotretinoin-induced premature fusion of growth plates seems to be associated with variable doses and durations of months to years. There have been reported cases of premature epiphyseal closure in individuals receiving therapeutic doses of isotretinoin for acne treatment, which are much lower compared to the high doses utilized for neuroblastoma. The growth plates of both the proximal tibia and distal femur may be affected by isotretinoin. This study increases recognition among primary care providers about the potentially harmful side effects of isotretinoin, including premature epiphyseal closure in the pediatric population. This helps providers better educate patients about the risks and benefits of isotretinoin therapy in order for them to make informed decisions. Further clinical research is needed to assess the development of growth plates in the pediatric population while utilizing isotretinoin therapy.

Research funding: None reported.

Author contributions: Both authors provided substantial contributions to conception and design, acquisition of data, or analysis and interpretation of data; both authors drafted the article or revised it critically for important intellectual content; both authors gave final approval of the version of the article to be published; and both authors agree to be accountable for all aspects of the work in ensuring that questions related to the accuracy or integrity of any part of the work are appropriately investigated and resolved.

Competing interests: None reported. 


\section{References}

1. Leyden JJ, Del Rosso JQ, Baum EW. The use of isotretinoin in the treatment of acne vulgaris: clinical considerations and future directions. J Clin Aesthet Dermatol 2014;7(2 Suppl):S3-21.

2. Zaenglein AL, Pathy AL, Schlosser BJ, Alikhan A, Baldwin HE, Berson DS, et al. Guidelines of care for the management of acne vulgaris. J Am Acad Dermatol 2016;74:945-73.e33.

3. Matthay KK, Villablanca JG, Seeger RC, Stram DO, Harris RE, Ramsay NK, et al. Treatment of high-risk neuroblastoma with intensive chemotherapy, radiotherapy, autologous bone marrow transplantation, and 13-cis-retinoic acid. Children's Cancer Group. N Engl J Med 1999;341:1165-73.

4. Otley CC, Stasko T, Tope WD, Lebwohl M. Chemoprevention of nonmelanoma skin cancer with systemic retinoids: practical dosing and management of adverse effects. Dermatol Surg 2006; 32:562-8.

5. Duvic M, Apisarnthanarax N, Cohen DS, Smith TL, Ha CS, Kurzrock R. Analysis of long-term outcomes of combined modality therapy for cutaneous T-cell lymphoma. J Am Acad Dermatol 2003;49:35-49.

6. U.S Food \& Drug Administration. Accutane drug label of 2010. Available from: https://www.accessdata.fda.gov/scripts/cder/ daf/ [Accessed 10 Jun 2021].

7. Milstone LM, McGuire J, Ablow RC. Premature epiphyseal closure in a child receiving oral 13-cis-retinoic acid. J Am Acad Dermatol 1982;7:663-6.

8. Luthi F, Eggel Y, Theumann N. Premature epiphyseal closure in an adolescent treated by retinoids for acne: an unusual cause of anterior knee pain. Joint Bone Spine 2012;79:314-6.

9. Steele RG, Lugg P, Richardson M. Premature epiphyseal closure secondary to single-course vitamin A therapy. Aust N Z J Surg 1999;69:825-7.

10. Brecher AR, Orlow SJ. Oral retinoid therapy for dermatologic conditions in children and adolescents. J Am Acad Dermatol 2003;49:171-86.

11. Lammer EJ, Chen DT, Hoar RM, Agnish ND, Benke PJ, Braun JT, et al. Retinoic acid embryopathy. N Engl J Med 1985;313:837-41.

12. Tkachenko E, Singer S, Sharma P, Barbieri J, Mostaghimi A. US food and drug administration reports of pregnancy and pregnancy-related adverse events associated with isotretinoin. JAMA Dermatol 2019;155:1175-9.

13. Lee YH, Scharnitz TP, Muscat J, Chen A, Gupta-Elera G, Kirby JS. Laboratory monitoring during isotretinoin therapy for acne: a systematic review and meta-analysis. JAMA Dermatol 2016;152: 35-44.

14. Kvist O, Luiza Dallora A, Nilsson O, Anderberg P, Sanmartin Berglund J, Flodmark CE, et al. A cross-sectional magnetic resonance imaging study of factors influencing growth plate closure in adolescents and young adults. Acta Paediatr 2021;110:1249-56.

15. Ağırdil Y. The growth plate: a physiologic overview. Efort Open Rev 2020;5:498-507.

16. Morales TI, Roberts AB. The interaction between retinoic acid and the transforming growth factors-beta in calf articular cartilage organ cultures. Arch Biochem Biophys 1992;293:79-84.

17. Standeven AM, Davies PJ, Chandraratna RA, Mader DR, Johnson AT, Thomazy VA. Retinoid-induced epiphyseal plate closure in guinea pigs. Fund Appl Toxicol 1996;34:91-8.

18. Hail N, Jr., Kim HJ, Lotan R. Mechanisms of fenretinide-induced apoptosis. Apoptosis 2006;11:1677-94.

19. Brazzell RK, Colburn WA. Pharmacokinetics of the retinoids Isotretinoin and etretinate. A comparative review. J Am Acad Dermatol 1982;6(2 Suppl):643-51.

20. U.S. Food and Drug Administration. FDA Adverse Events Reporting System (FEARS). Available from: https://fis.fda.gov/sense/app/ d10be6bb-494e-4cd2-82e4-0135608ddc13/sheet/33a0f68e845c-48e2-bc81-8141c6aaf772/state/analysis [Accessed $12 \mathrm{Apr}$ 2021].

21. Duvalyan A, Cha A, Goodarzian F, Arkader A, Villablanca JG, Marachelian A. Premature epiphyseal growth plate arrest after Isotretinoin therapy for high-risk neuroblastoma: a case series and review of the literature. Pediatr Blood Canc 2020;67: e28236.

22. Matsuoka M, Onodera T, Majima T, Iwasaki K, Takahashi D, Kondo E, et al. Correction osteotomy for bilateral varus knee deformity caused by premature epiphyseal closure induced by hypervitaminosis A: a case report. BMC Muscoskel Disord 2019; 20:287.

23. Park WK, Choi HS, Chung CY, Park MS, Sung KH. Genu varum deformity due to premature epiphyseal closure after treatment with isotretinoin for neuroblastoma: a case report. J Orthop Surg 2020;28:2309499020924483.

24. Marini JC, Hill S, Zasloff MA. Dense metaphyseal bands and growth arrest associated with isotretinoin therapy. Am J Dis Child 1988;142:316-8.

25. DiGiovanna JJ. Isotretinoin effects on bone. J Am Acad Dermatol 2001;45:S176-82.

26. Lucky AW, Biro FM, Simbartl LA, Morrison JA, Sorg NW. Predictors of severity of acne vulgaris in young adolescent girls: results of a five-year longitudinal study. J Pediatr 1997;130:30-9.

27. Lee PA. Normal ages of pubertal events among American males and females. J Adolesc Health Care 1980;1:26-9.

28. Odsbu I, Selmer R, Stålsby Lundborg C, Blix HS. Increased prescribing of systemic tetracyclines and Isotretinoin for treatment of acne. J Antimicrob Chemother 2017;72:1510-5. 